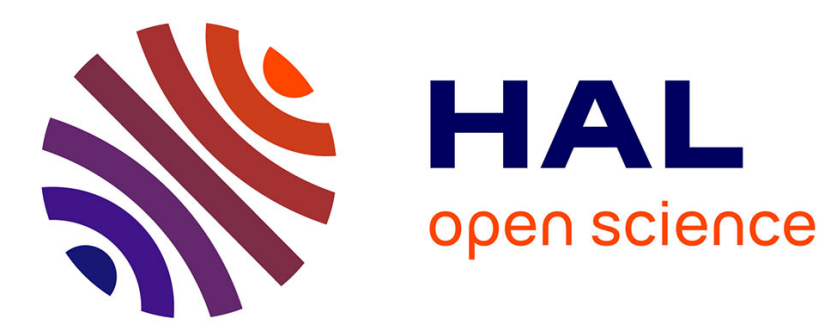

\title{
Late Devonian benthic ostracods from western Junggar, NW China: Implications for palaeoenvironmental reconstruction
}

\author{
Junjun Song, S. Crasquin, Yiming Gong
}

\section{To cite this version:}

Junjun Song, S. Crasquin, Yiming Gong. Late Devonian benthic ostracods from western Junggar, NW China: Implications for palaeoenvironmental reconstruction. Geological Journal, 2019, 54 (1), pp.91-100. 10.1002/gj.3156 . hal-02613928

\section{HAL Id: hal-02613928 \\ https://hal.science/hal-02613928}

Submitted on 11 Dec 2020

HAL is a multi-disciplinary open access archive for the deposit and dissemination of scientific research documents, whether they are published or not. The documents may come from teaching and research institutions in France or abroad, or from public or private research centers.
L'archive ouverte pluridisciplinaire HAL, est destinée au dépôt et à la diffusion de documents scientifiques de niveau recherche, publiés ou non, émanant des établissements d'enseignement et de recherche français ou étrangers, des laboratoires publics ou privés. 


\title{
Late Devonian benthic ostracods from the western Junggar, NW China:
}

\author{
Implications for palaeoenvironmental reconstruction \\ JUNJUN SONG ${ }^{1,2}$, SYLVIE CRASQUIN $^{2}$ and YIMING GONG $^{1}$ \\ ${ }^{1}$ State Key Laboratory of Biogeology and Environmental Geology, School of Earth Sciences, China University of \\ Geosciences, Wuhan 430074, China; e-mails: hnlisa@126.com, ymgong@cug.edu.cn \\ ${ }^{2}$ CR2P, MNHN-UPMC, CNRS, Sorbonne Universités, Université Pierre et Marie Curie, T46-56, E.5, case 104, \\ 75252 Paris cedex 05, France; e-mail: sylvie.crasquin@upmc.fr
}

Abstract- This study focuses on palaeoecology and palaeobiogeography of Late Devonian ostracods based on more than 4500 carapaces collected from sections in the western Junggar, NW China. According to the ostracod faunas from the Hongguleleng Formation, three ecological assemblages for an open oceanic island arc are proposed, i.e., OA1 (Ostracod Assemblage-1), OA2 (Ostracod Assemblage-2) and OA3 (Ostracod Assemblage-3). They characterize foreshore, nearshore and offshore, respectively. Water energy should be the first environmental factor controlling the composition of the ostracod assemblages from the Lower Member of the Hongguleleng Formation, and salinity fluctuations could be also involved. Many cosmopolitan species were present in the diversified ostracod faunas of the Hongguleleng Formation, suggesting possible biogeographic relationships between the Kazakhstan Plate and South China, North America and Russian plates. The ostracods from Late Devonian of the Kazakhstan Plate might migrate to the South China Block and Laurentia-Baltica by ocean currents and sea-level changes, which also implies that neritic faunal exchanges were possible along the Palaeo-Tethys 
during the Late Devonian.

Keywords: Ostracods, palaeoecology, palaeobiogeography, Late Devonian, western Junggar

\section{Introduction}

Ostracoda are microcrustacea appeared in the Early Ordovician and still developed today (Horne et al., 2002; Siveter, 2008). They are very sensitive to the ambient environment conditions and variations, such as salinity, bathymetry, temperature, hydrodynamics, oxygenation and nutrients supply, etc.(Casier and Olempska, 2008; Olempska and Belka, 2010; Jones, 2011; Racheboeuf et al., 2012; Maillet et al., 2013). Ostracods may offer special insights into the characteristics and evolution of the Devonian global bio-environments (Lethiers, 1983; Lethiers and Raymond, 1991; Becker and Braun, 2008; Song and Gong, 2017).

Until recently, most studies on palaeoecology of the Devonian ostracods have been conducted on continental margins or in epicontinental basins, primarily in Europe and North America (e.g., Becker, 1964, 1965, 1971, 2000; Bandel and Becker, 1975; Becker and Bless, 1987; Casier, 2004, 2008, 2017; Maillet et al., 2013), as well as South China (Wang, 1988, 2009). Casier (2004, 2008) proposed a new ostracod assemblage denomination, i.e. Eifelian Mega-Assemblage (=Assemblages 0-III), Thüringian Mega-Assemblage (=Assemblage IV) and Myodocopid Mega-Assemblage (=Assemblage V), which express the palaeoenvironments from the nearshore to deep basins. Similarly, five ostracod associations were recognized in the Palaeozoic strata of South China (Wang, 1988, 
2009) i.e., the leperditiid, palaeocopid, smooth-podocopid, spinose-podocopid and entomozoacean associations. In contrast, the palaeoecology of ostracods in an open oceanic setting far from continental-derived sediments remain poorly known. In this paper, all the samples of ostracods were collected from the western Junggar, NW China, featured by the archipelago during the Palaeozoic (Gong and Zong, 2015). Studies of sedimentary petrology and trace element geochemistry indicate that the Late Devonian Hongguleleng Formation was deposited with intermittent periods of volcanic activities (Carmichael et al., 2014, 2016; Fan and Gong, 2016).

Thus, the main aim of this study is to assess the influence of palaeoenvironmental changes in the open oceanic island arc on the distribution and composition of ostracod assemblage, and discuss their special significance in palaeogeography of Palaeo-Tethys during the Late Devonian.

\section{Geological setting and section descriptions}

The western Junggar region (WJR) is located in the northwest of Xinjiang Uygur Autonomous Region (referred as Xinjiang), NW China, where the Kazakhstan, Siberia and Tarim plates join. WJR is an important component of the Central Asian Orogenic Belt (CAOB) during the Palaeozoic (Cocks and Torsvik, 2007; Windley et al., 2007; Gong and Zong, 2015). The study area belongs to the Late Devonian volcanic arc setting (Xiao et al., 2010), with widespread Palaeozoic sedimentary rocks and various types of volcanic produces (Fig. 1). Mostly Late Devonian Hongguleleng Formation were deposited in the back-arc basin of the Zharma-Saur arc in the Shaerbuerti Mountains (Fig. 1), where yielded abundant and diversified faunas (e.g., 
brachiopods, bryozoans, conodonts, trilobites, plants, etc.) (Xu et al., 1990; Xia,1996; Windley et al., 2007; Chen et al., 2009; Suttner et al., 2014; Wang et al., 2016) and trace fossils (Fan and Gong, 2016).

In our study, fieldworks had been carried out in four sections, namely the Wulankeshun, Bulongour, Gennaren and Emuha sections (Fig. 2A). The Late Devonian Hongguleleng Formation crops out well with abundant fossils in the first three sections, which have similar lithology, especially in the Wulankeshun and Bulongour sections (Fig. 2). Unfortunately, most of the Upper Devonian is missing in the Emuha section (Song and Gong, 2015). Therefore, this paper focused on the ostracods collected from the Hongguleleng Formation in the Wulankeshun and Bulongour sections, and the results of systematic palaeontology has already been published (Song et al., 2017).

The Wulankeshun section (N 46 46'05.12"; E 8454'43.98", hereinafter referred as WLS) is located approximately $65 \mathrm{~km}$ west of Hebukesar Mongol Autonomous County (Figs 1, 2). It exhibits continuous outcrop from the Late Devonian to Early Carboniferous (Wang et al., 2015): series of the Zhulumute, Hongguleleng to Heishantou formations without major tectonic deformation (Fig. 2). The Hongguleleng Formation (372.4 m thick) could be divided into three members: the Lower Member is made of grey, grey-yellow bioclastic limestones; the Middle Member consists of variegated fine-grained volcaniclastic rocks and the Upper Member is composed of grey-green, grey yellow bioclastic limestones and calcareous-pelitic clastic rocks (Fig. 2). 
The Bulongour section (N 46 $45^{\prime} 10.26^{\prime \prime}$; E 86 08'20.70", hereinafter referred as BLS) is located in the north of Hoxtolgay, about $1.5 \mathrm{~km}$ northwest of the Bulongour Reservoir (Figs 1, 2), and about $90 \mathrm{~km}$ east to the WLS. This is the type section of the Hongguleleng Formation and has been extensively studied previously (e.g., Xu et al., 1990; Chen et al., 2009; Suttner et al., 2014). In this study, the sampling is concentrated the Lower Member of the Hongguleleng Formation in both sections for well-preserved ostracods fossils in the limestones.

Extensive works on the Hongguleleng Formation had been carried out by our research group forehand, especially in the WLS for conodont biostratigraphy (Wang et al., 2016), sedimentary (Fan and Gong, 2016) and geochemistry (Wang, 2016). In this paper, the palaeoenvironment of the Lower Member of the Hongguleleng Formation summarized the results of Fan and Gong (2016) and Wang (2016). Fan and Gong (2016) gave an overview on sedimentary structure and trace fossils from both WLS and BLS, Wang (2016) studied the conodont biofacies and microfacies from WLS. Totally, four palaeoenvironments could be recognized from the bottom to top in the Lower Member of the Hongguleleng Formation, i.e., foreshore (bed 18 of WLS and bed $1 \mathrm{~A}$ of BLS), nearshore (bed 19 and beds 22-23 of WLS, bed 1B and bed 3 of BLS) and offshore (beds 20-21 of WLS and bed 2 of BLS). 


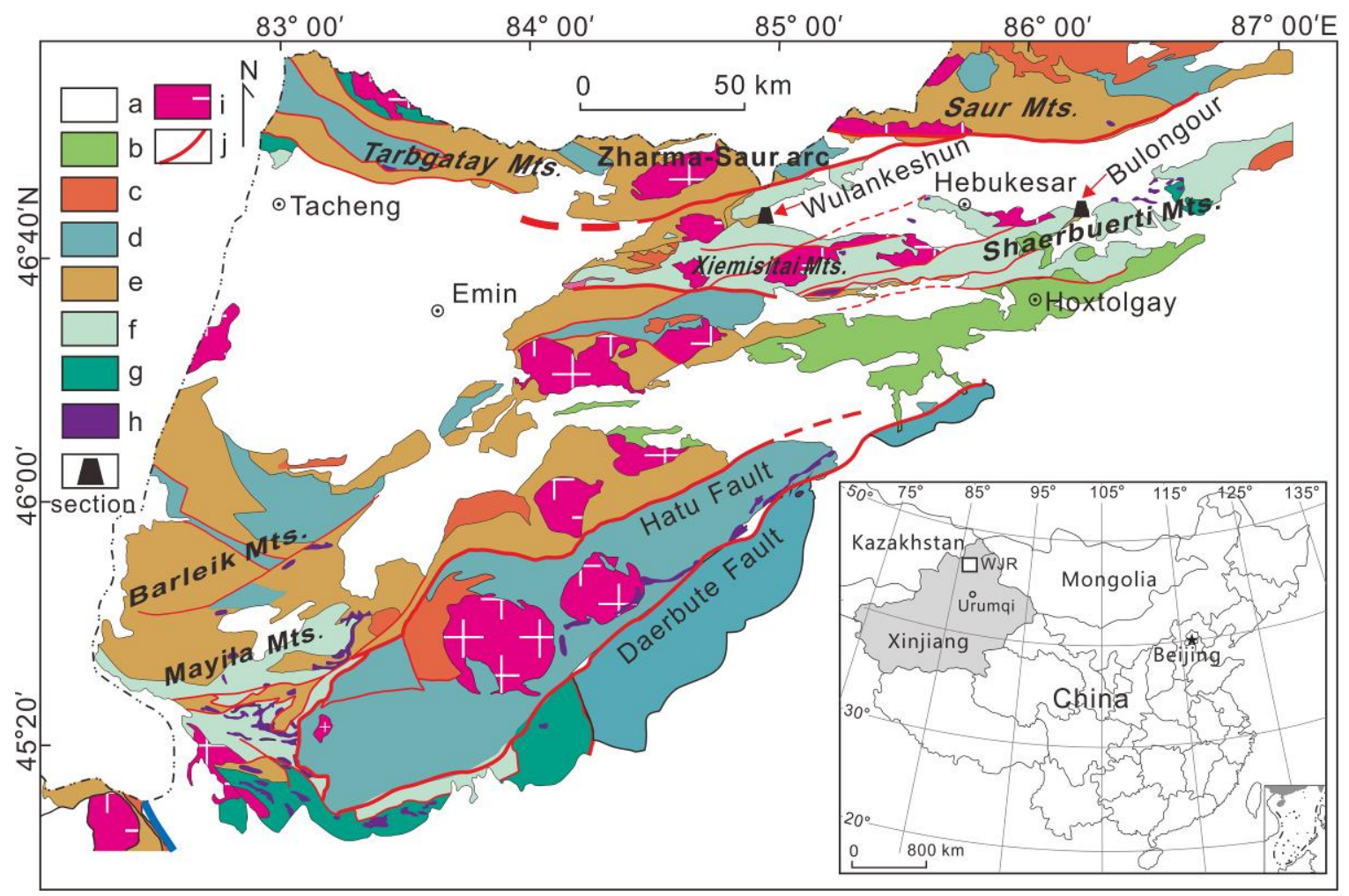

Fig.1. Location map of the studied sections and simplified geology in the western Junggar, NW China (modified after Gong and Zong, 2015). a-Quaternary; b-Mesozoic; c-Permian; d-Carboniferous; e-Devonian; f-Silurian; g-Ordovician; h- ophiolite; i- granite; $j$ - fault 


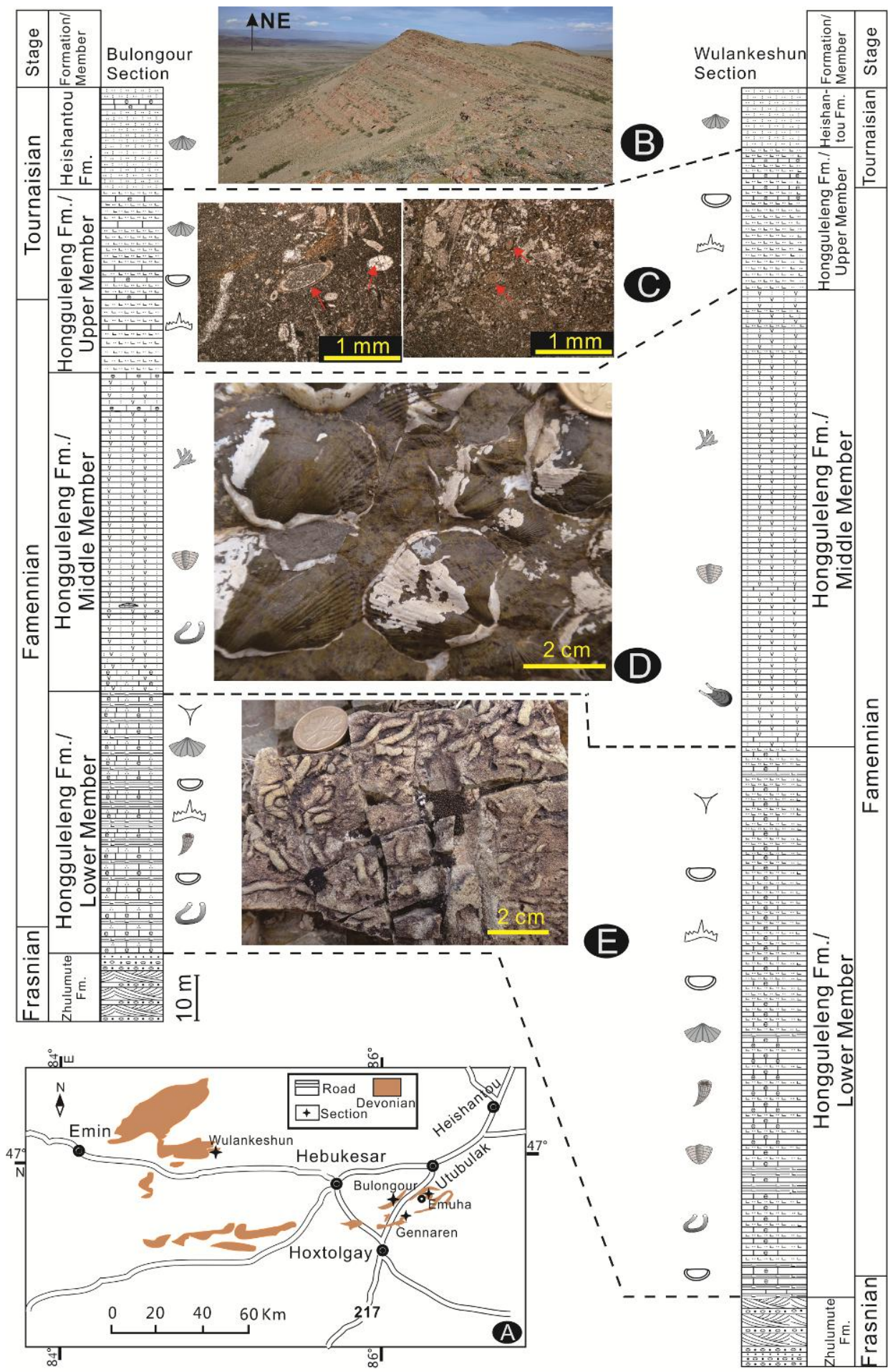

ostracods $M$ my conodonts corals $\nabla$ bryozoans brachiopods $\Theta$ crinoids trilobites

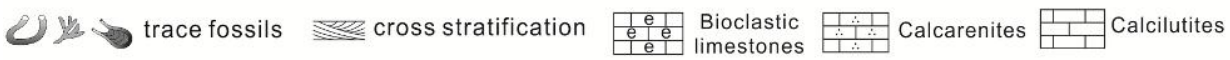

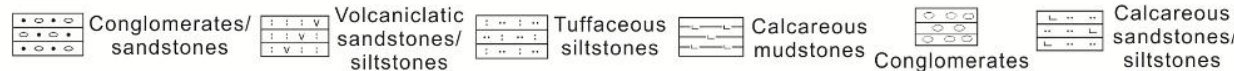

Fig.2. Correlations between the Wulankeshun and Bulongour sections in the western Junggar, NW China (modified after Song et al., 2017). A- Locations of sections; B- View of the Lower Member of the Hongguleleng Formation in the WLS; C-Thin sections of rocks from the Hongguleleng Formation in the BLS; D- Brachiopods in the Lower Member of the Hongguleleng Formation in the WLS; E- Trace fossils in the Upper Member of the Hongguleleng Formation in the WLS. 


\section{Materials}

213 samples were collected by our working group from the Wulankeshun, Bulongour and Gennaren sections from 2011 to 2016. More than 4500 carapaces, valves and fragments of ostracods were extracted from limestones by hot-acetolysis (Lethiers and Crasquin-Soleau, 1988; Crasquin-Soleau et al., 2005). Among them, about 2500 and 1900 specimens were obtained from the BLS and WLS, respectively. 53 species belonging to 31 genera were recognized: 45 species belonging to 29 genera from the BLS and 49 species belonging to 28 genera from the WLS (Song et al., 2017). The ostracod faunas from all the Lower Member of the Hongguleleng Formation are dominated by Metacopina (i.e., Bairdiocypridoidea, Healdioidea and Quasillitoidea), Podocopida (i.e., Bairdioidea), Palaeocopida (e.g., Hollinoidea, Primitiopsoidea and Paraparchitoidea), Platycopida (Kloedenelloidea) and Myodocopida (Entomozoidea) (Song et al., 2017; Table 1).

Table 1 Numbers of species per bed in the studied sections (summarized from Song et al., 2017)

\begin{tabular}{|c|c|c|c|c|c|c|c|c|c|c|}
\hline \multirow{2}{*}{ Order } & \multirow{2}{*}{$\begin{array}{l}\text { Superfamily/ } \\
\text { Family }\end{array}$} & \multicolumn{3}{|c|}{ Bulongour } & \multicolumn{6}{|c|}{ Wulankeshun } \\
\hline & & bed 1 & bed 2 & bed 3 & bed 18 & bed 19 & bed 20 & bed 21 & bed 22 & bed 23 \\
\hline \multirow{7}{*}{ Palaeocopida } & Beyrichioidea & 0 & 0 & 1 & 0 & 0 & 0 & 0 & 0 & 0 \\
\hline & Hollinoidea & 5 & 4 & 2 & 4 & 6 & 4 & 5 & 3 & 3 \\
\hline & Primitiopsoidea & 1 & 1 & 1 & 1 & 1 & 1 & 1 & 1 & 1 \\
\hline & Kirkbyoidea & 0 & 1 & 1 & 1 & 1 & 0 & 1 & 0 & 0 \\
\hline & Cryptophyllidae & 1 & 0 & 0 & 0 & 0 & 0 & 0 & 0 & 0 \\
\hline & Paraparchitoidea & 2 & 2 & 2 & 3 & 2 & 1 & 1 & 1 & 0 \\
\hline & Youngielloidea & 1 & 1 & 1 & 0 & 1 & 1 & 1 & 1 & 1 \\
\hline Platycopida & Kloedenelloidea & 3 & 4 & 2 & 2 & 2 & 3 & 3 & 2 & 0 \\
\hline Podocopida & Bairdioidea & 1 & 11 & 5 & 1 & 10 & 10 & 8 & 6 & 4 \\
\hline
\end{tabular}




\begin{tabular}{|c|c|c|c|c|c|c|c|c|c|c|}
\hline & Bairdiocypridoidea & 3 & 7 & 10 & 1 & 8 & 8 & 9 & 7 & 4 \\
\hline \multirow[t]{2}{*}{ Metacopina } & Quasillitoidea & 0 & 0 & 1 & 1 & 0 & 0 & 0 & 0 & 0 \\
\hline & Healdioidea & 2 & 4 & 3 & 2 & 3 & 4 & 3 & 2 & 2 \\
\hline Myodocopida & Entomozoidea & 0 & 1 & 0 & 0 & 0 & 1 & 1 & 0 & 0 \\
\hline
\end{tabular}

\section{Ecology of ostracod assemblages from the Hongguleleng Formation}

\subsection{Ecological assemblages of ostracods}

The ostracod assemblages from the Lower Member of the Hongguleleng Formation vary with environments, and three ecological assemblages of ostracods could be defined as follows (Figs. 3, 4).

OA1 (Ostracod Assemblage-1) is located in the foreshore (Fig. 4), characterized by ostracods from the bed 18 of the WLS and the bed 1A of the BLS. The ostracod fauna is rather rare with few species (18 species in the WLS; 15 species in the BLS) were discovered in mostly small number. The assemblage is dominated by Hollinidea Swartz, 1936, including of two families, Hollinidae and Pribylitidae. Specifically, the Palaeocopida, i.e., Hollinoidea (Hollinella Coryell, 1928, Parabolbinella Adamczak, 1968, Pribylites Pokorný, 1951), Paraparchitidae (Guerichiella Adamczak, 1968), Primitiopsidae (Paraparchites Ulrich \& Bassler, 1906, Samarella Polenova, 1952), Amphissitidae (Amphissites Girty, 1910), Youngiellidae (Moorites Coryell \& Billings, 1932) and Cryptophyllidae (Cryptophyllus Levinson, 1951) show a significant advantage on OA1 and represent more than $50 \%$ and $70 \%$ of total number of species in the WLS and BLS, respectively. Among them, the first five families/superfamilies were occurred in two sections, while Crytophyllidae only appeared in the BLS. Besides the domination superfamily Hollinoidea (about $34 \%$ of total number of 
species), Paraparchitidae shows relatively high abundance and diversity (about $15 \%$ of total number of species). Metacopina may account for $30 \%-40 \%$ of total number of species (WLS: 33\%; BLS: 37\%), which is mainly made up of Healdioidae (i.e., Arcuaria Neckaja, 1958, Cribroconcha Cooper, 1941; about 13\% of total number of species) and a few Bairdiocyprididae (Praepilatina Polenova, 1970) and Pachydomellidae (Microchelinella Geis, 1933). Moreover, rare platycopids (Kloedenelloidea) of OA1 just appeared in the bed 18 of the WLS, accounting for $8 \%$ of total number of species. Notably, there is no Bairdioidea in the OA1. The endemic taxa (Song et al., 2017) (e.g., Pribylites wulankeshunensis Song \& Crasquin, 2017, P. junggarensis Song \& Crasquin, 2017, Microchelinella hoxtolgayensis Song \& Crasquin, 2017, M. bulongourensis Song \& Crasquin, 2017, Arcuaria hebukesarensis Song \& Crasquin, 2017 and Cribroconcha honggulelengensis Song \& Crasquin, 2017) are common and abundant in OA1.

Morphologically, Palaeocopida are characterized by straight dorsal border. They should survive in the high-energy environment as crawlers with small size and thick carapaces. Similarly, some genera of Metacopina (such as Praepilatina Polenova, 1970 and Microchelinella Geis, 1933) should be benthic crawler with small-sized (length of carapaces is less than $0.95 \mathrm{~mm}$; Beck, 1971), thick shell and low gravity.

On the whole, OA1 is dominated by Palaeocopida without any Bairdioidea, which similar to the 'Eifelian Mega-Assemblage-1' from Europe and North America (e.g., Becker, 1971, 2000; Bandel and Becker, 1975; Casier, 2004, 2008) and the 'Palaeocopid association' from South China (Wang, 1988, 2009) (Table 2). However, 
compared with ostracod faunas in the two ecotypes above, most taxa in OA1 are smooth small-sized, and the domination and common taxa are different. For example, beyrichiids, cavellinids and leperditiids, which are common and abundant in both Eifelian Mega-Assemblage and Palaeocopida association, whereas are absent from the OA1.

OA2 (Ostracod Assemblage-2) is located in the nearshore (Figs 3, 4), characterized by ostracods from the bed 19 and beds $22-23$ of the WLS and the bed 1B and bed 3 of the BLS. It is dominated by Bairdiocypridoidea, including of two families, i.e., Bairdiocyprididae and Pachydomellidae. The diversity and abundance of ostracods in OA2 are higher than that in OA1, and 27 species and 29 species presented in the WLS and the BLS, respectively. Bairdiocypridoidea (Bairdiocypris Kegel, 1932, Healdiacypris Bradfield, 1935, Praepilatina Polenova, 1970 and Pseudobythocypris Shaver, 1958; about 35\% of total number of species) and Bairdioidea (Bairdia McCoy, 1844, Fabalicypris Cooper, 1946 and Acratia Delo, 1930; about 25\% of total number of species). Palaeocopida (20\%-25\% of total number of species) is dominated by Hollinoidea (Pribylites Pokorný, 1951) and Paraparchitidae (Guerichiella Adamczak, 1968) but with lower abundance and diversity. Platycopida (i.e., Kloedenelloidea, about $20 \%$ of total number of species) is more abundant than that in OA1.

Although the smooth-podocopids dominated the ostracods of OA2, the percentage of Bairdioidea (about $40 \%$ of podocopid species) is much smaller than that in ‘smooth-podocopid association' from South China (Wang, 1988) (Table 2), which is $80 \%-90 \%$ of total numbers of species of podocopids. Moreover, the domination 
taxa of OA2, some genera of Bairdiocyprididae, e.g., Praepilatina Polenova, 1970 and Pseudobythocypris Shaver, 1958 could appeared in deep water along with 'spinose-podocopids association' in South China (Wang, 1988) and Thüringian Mega-Assemblage in Europe and North America (Becker, 2000; Casier, 2004) more frequently than in the shallow-water environment as the Lower Member of the Hongguleleng Formation.

OA3 (Ostracod Assemblage-3) is located in the offshore (Figs. 3, 4), marked by ostracods from the beds $20-21$ of the WLS and the bed 2 of the BLS. The ostracods of OA3 were discovered in relatively large number in both two sections, especially the WLS, where 43 species belong to 26 genera were recognized. The ostracod faunas from OA3 are dominated by smooth Podocopida and Metacopina (about 60\%-65\% of total number of species), including of Bairdioidea (Bairdia McCoy, 1844, Fabalicypris Cooper, 1946, Acratia Delo, 1930 and Famenella Polenova, 1953), Bairdiocyprididae (Bairdiocypris Kegel, 1932, Healdiacypris Bradfield, 1935, Praepilatina Polenova, 1970 and Pseudobythocypris Shaver, 1958) and Healdioidae (Bairdiocypris Kegel, 1932, Praepilatina Polenova, 1970 and Pseudobythocypris Shaver, 1958) with high diversity and abundance, as well as a few of Bufinidae (i.e., Aurigerites Roundy, 1926). Among them, the Bairdioidea presented in a large number that more than $60 \%$ of total number of podocopids species. Compared with the ostracods of OA2, the Bairdioidea is more abundant in OA3, while Bairdiocypridoidea is lower in abundance. Palaeocopida make up 30\% of total number of species, which consists of Hollinoidea, Paraparchitidae, Primitiopsidae, 
Amphissitidae, Cryptophyllidae and Youngiellidae. Hollinoidea is still dominating in the Palaeocopida of OA3 as that in OA1, including of four genera (Hollinella Coryell, 1928, Parabolbinella Adamczak, 1968, Pribylites Pokorný, 1951 and Parasargentina Zheng, 1982). Platycopida (including 3 genera, Sargentina Coryell \& Johnson, 1939, Quasiknoxiella Tschizova, 1977 and Knoxiella Egorov, 1950) and Myodocopida are rare in the OA3, just $5 \%-10 \%$ and $5 \%$ of total number of species.

Overall, the ostracod faunas of $0 \mathrm{~A} 3$ are characterized by Bairdioidea and Bairdiocyprididae with large-sized (length of carapaces is more than 1.40 mm; Beck, 1971) and smooth shell, which suggest to be benthic. This is a little similar to the 'Eifelian Mega-Assemblage-2-3'(Casier, 2004, 2008) and the ‘smooth-podocopid association’ (Wang, 1988, 2009) (Table 2). Nevertheless, what is noticeable is that some Entomozoidea were realized with relatively high abundance in the OA3 from both WLS and BLS, though only one species (Franklinella latesulcata (Paeckelmann), 1921; Fig. 5). Moreover, more species of Entomozoidea (2 species belonging to 2 genera; Fig. 5) were discovery in relatively large number from the same environment in the Gennaren section, which is not far away from BLS. Previous studies have indicated that entomozoaceans (pelagic 'finger-print' ostracods) prefer swimming in low-energy deeper waters (Bandel and Beker, 1975; Casier et al., 1995; Becker and Bless, 1987; Wang, 1988; Lethiers and Casier, 1995; Olempska, 2002; Casier, 2004, 2008), reflecting an environment of deep-water basin in general (Wang, 1988). As for biocoenoses, mixtures between the Eifelian and the Entomozoacean assemblages had never been observed in Europe or South China (Becker and Bless, 
1990). Villozona Gründel, 1965 appeared in OA3 from the WLS (Fig. 5), which was only known from basinal environments (Thuringia, Morocco, South China) previously (Gründel, 1965; Becker, 2000), and never reported in shallow marine yet. There may be two interpretation to explain the uncommon melange. One is that some species of Entomozoidea and Villozona might be able to expand to the shallow water from slop or deep basin under particular environment. The other is that the complicated back-arc basin environment with short shelf and sharp slope may offer possibility to the mixtures of ostracods from shallow and deep water. In the study, we tend to the second hypothesis because of the sedimentary data and geological setting (Gong and Zong, 2015; Wang, 2016). Actually, the uncommon mixtures reflect that the ecology of ostracods is more flexible and complicated from open oceanic island arc than that from continental margins.

Totally, the common species in the three ostracod assemblages are Guerichiella cf. pulchra, Moorites copelandi and most of endemic taxa (e.g., Pribylites wulankeshunensis, Pribylites junggarensis, Arcuaria hebukesarensis, Cribroconcha honggulelengensis and Microchelinella hoxtolgayensis) (Fig. 5). All of them are thick shells, small-sized and smooth or simple ornamented (e.g., Guerichiella cf. pulchra, Moorites copelandi and Pribylites wulankeshunensis), suggesting to be crawlers or burrowers and survived in the high-energy and great turbulence waters, alike the Hongguleleng Formation that was totally affected by the storm as depositing (Fan and Gong, 2016). 


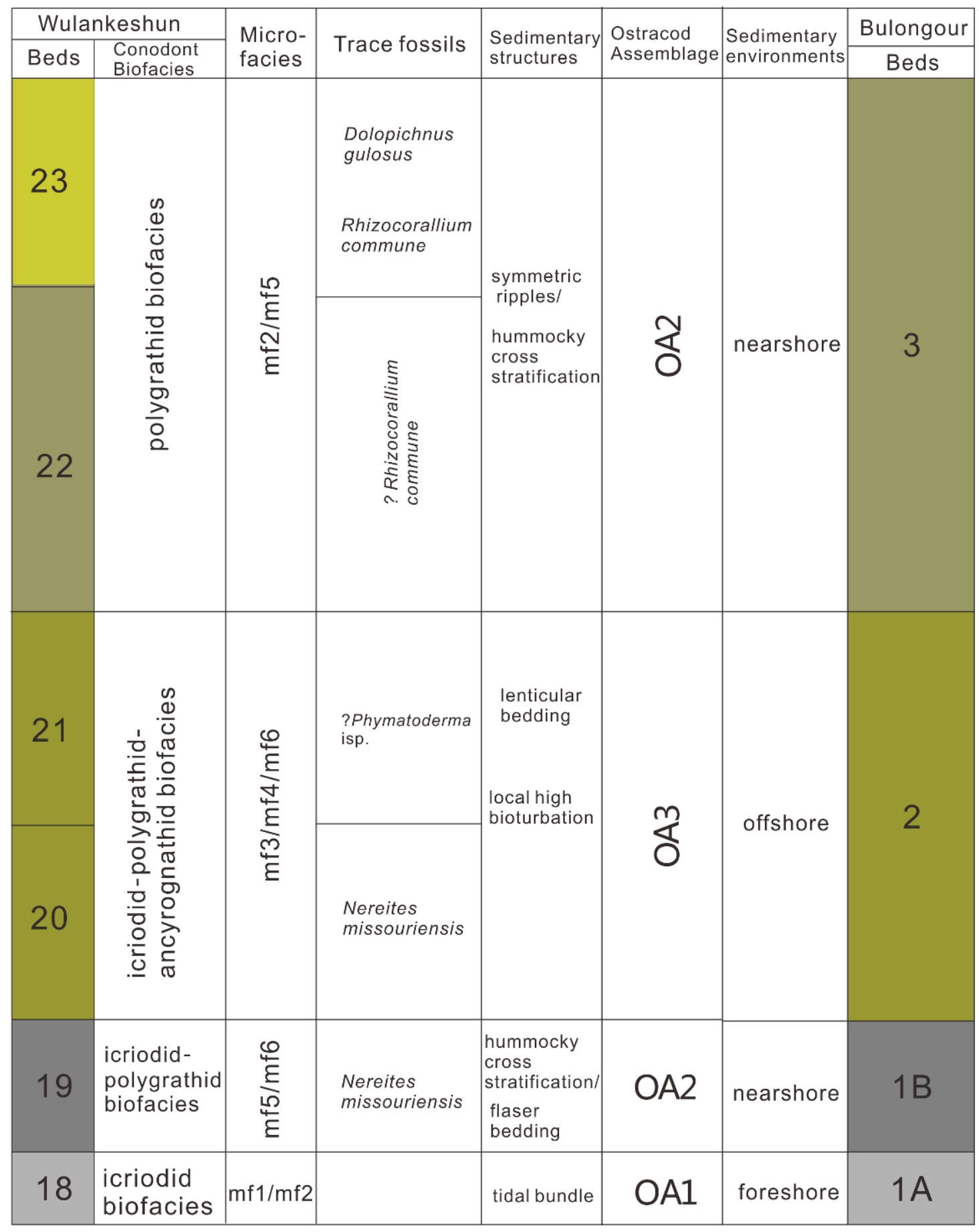

Fig.3. Distribution of sedimentary environments and ostracod assemblages from the Lower Member of the Hongguleleng Formation in the WLS and BLS, the western Junggar, NW China. Conodont biofacies from Wang, (2016) ; trace fossils from Fan and Gong (2016) ; microfacies types (mf1-6) modified after Wang , (2016) , mf1-mudstone with fine-grained bioclasts; mf2-wackestone-packstone with fine-grained bioclasts; mf3- mudstone-wackestone with fine-grained bioclasts; mf4-wackestone with fine-grained bioclasts; mf5- packstone with bioclasts; e. mf6- grainstone with coarse-grained bioclasts. 
Table 2. Comparison of the ecological assemblages of neritic ostracods in the Palaeozoic from the western Junggar, Europe and South China

\begin{tabular}{|c|c|c|c|c|c|c|c|}
\hline \multicolumn{2}{|c|}{$\begin{array}{c}\text { Europe } \\
\text { (Bandel and Becker,1971;Casier, 2008) }\end{array}$} & \multirow{2}{*}{$\begin{array}{l}\text { Sedimentary } \\
\text { environments }\end{array}$} & \multicolumn{2}{|c|}{$\begin{array}{l}\text { South China } \\
\text { (Wang, 1988) }\end{array}$} & \multicolumn{3}{|c|}{ Western Junggar } \\
\hline Assemblage & $\begin{array}{l}\text { Characteristic } \\
\text { faunas }\end{array}$ & & Assemblage & $\begin{array}{l}\text { Characteristic } \\
\text { faunas }\end{array}$ & $\begin{array}{l}\text { Assem- } \\
\text { blage }\end{array}$ & $\begin{array}{l}\text { Characteristic } \\
\text { faunas }\end{array}$ & $\begin{array}{l}\text { Sedimentary } \\
\text { environments }\end{array}$ \\
\hline $\begin{array}{l}\text { Eifelian Mega- } \\
\text { Assemblage-0 }\end{array}$ & Leperditicopida & lagoon & $\begin{array}{l}\text { Leperditild } \\
\text { association }\end{array}$ & leperditiids & OA1 & Hollinoidea & foreshore \\
\hline $\begin{array}{l}\text { EifelianMega- } \\
\text { Assemblage-1 }\end{array}$ & $\begin{array}{l}\text { Palaeocopina } \\
\text { Platycopina }\end{array}$ & nearshore & $\begin{array}{l}\text { Palaeocopid } \\
\text { association }\end{array}$ & $\begin{array}{l}\text { beyrichiids } \\
\text { Platycopina }\end{array}$ & OA2 & Bairdiocypridoidea & nearshore \\
\hline $\begin{array}{l}\text { Eifelian Mega- } \\
\text { Assemblage-2,3 }\end{array}$ & $\begin{array}{l}\text { Podocopina } \\
\text { Palaeocopina } \\
\text { Platycopina }\end{array}$ & offshore & $\begin{array}{l}\text { Smooth- } \\
\text { podocopid } \\
\text { association }\end{array}$ & bairdioidea & OA3 & Bairdioidea & offshore \\
\hline
\end{tabular}

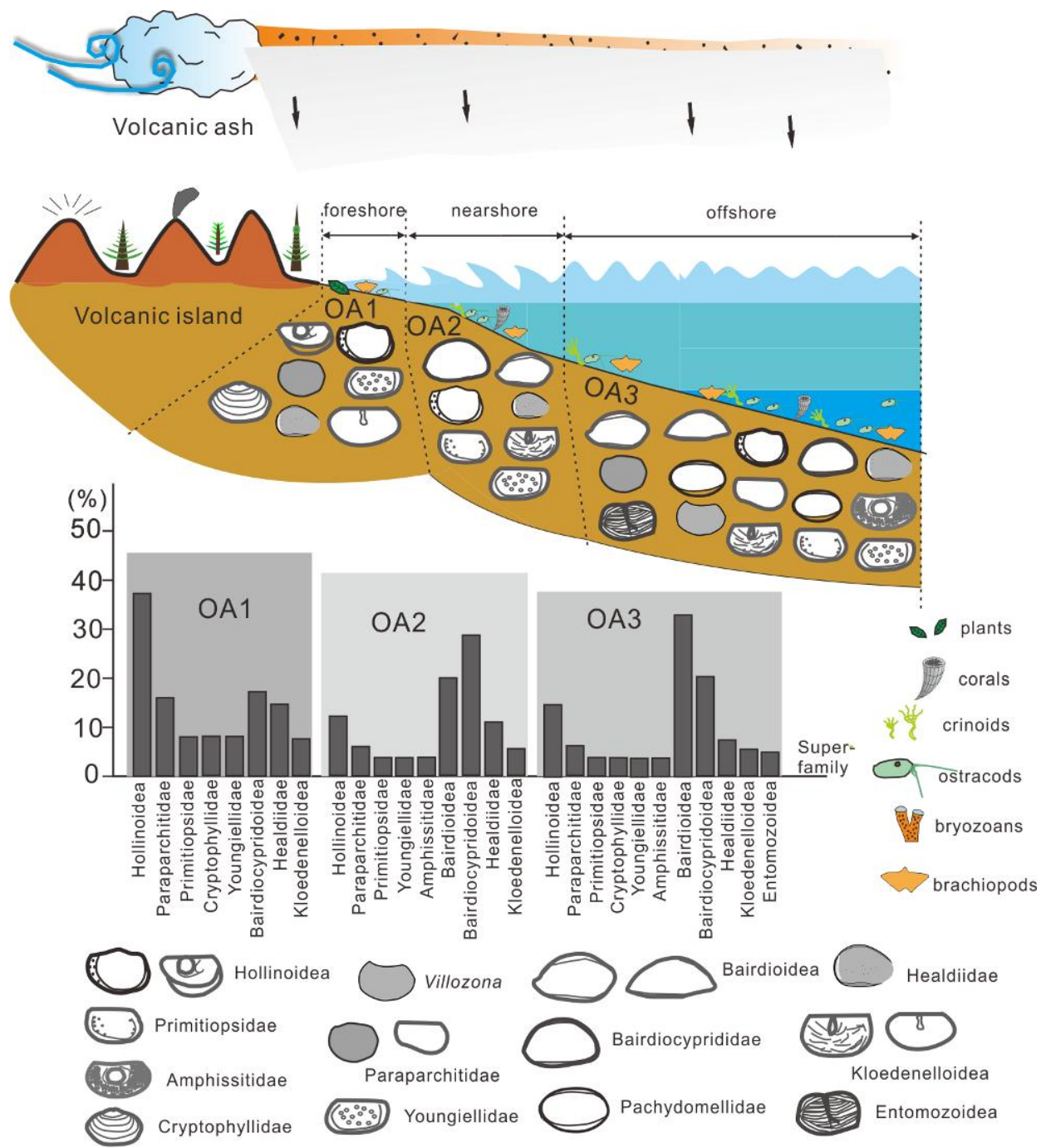

Fig.4. Palaeoenvironments and ostracod assemblages from the Lower Member of the Hongguleleng Formation, the western Junggar, NW China 


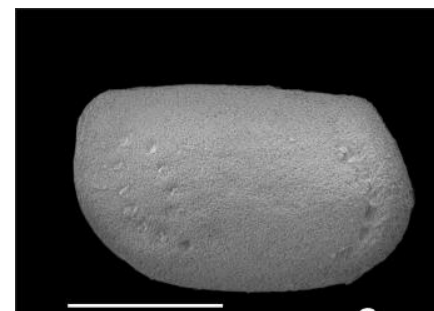

a

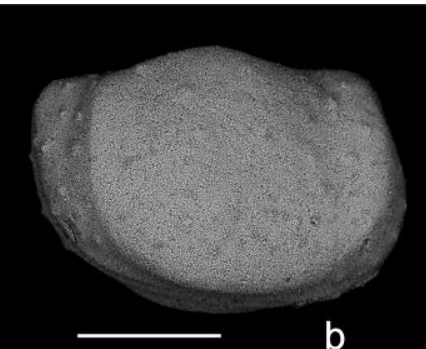

b

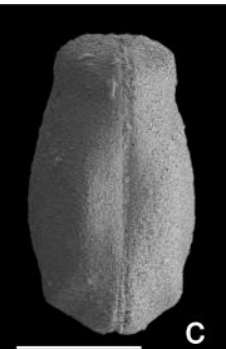

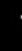

$\longrightarrow$

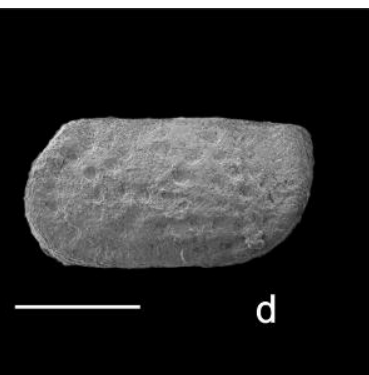

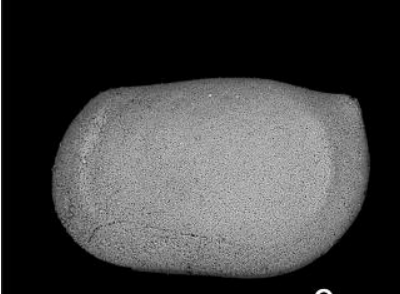

e
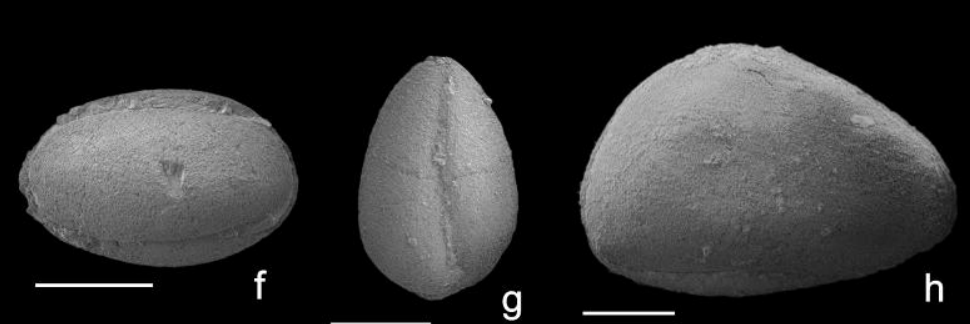

g
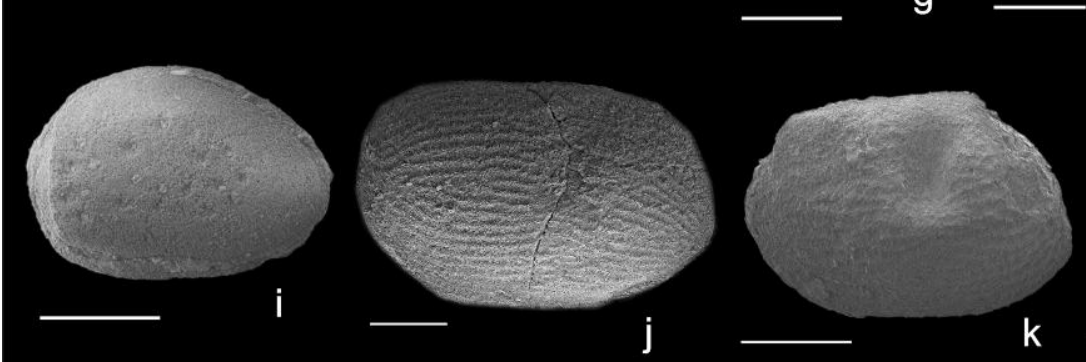

$\mathrm{k}$

Fig. 5. Common species of ostracods from the Upper Devonian Hongguleleng Formation of the western Junggar, NW China. a. Guerichiella cf. pulchra Wei, 1988. Right lateral view of complete carapace, WZ15007. b, c. Pribylites wulankeshunensis Song \& Crasquin, 2017. Right lateral view and dorsal view of complete carapace, respectively, WZ15008. d. Moorites copelandi Lethiers, 1981. Right lateral view of complete carapace, WZ15018. e. Pribylites junggarensis Song \& Crasquin, 2017. Right lateral view of complete carapace, WZ15011. f, g. Microchelinella hoxtolgayensis Song \& Crasquin, 2017. f, right lateral view of complete carapace, WZ15050; g, dorsal view of complete carapace, WZ15052. h. Arcuaria hebukesarensis Song \& Crasquin, 2017. Right lateral view of complete carapace, WZ15056. i. Cribroconcha honggulelengensis Song \& Crasquin, 2017. Right lateral view of complete carapace, WZ15059. j. Nehdentomis schmidti Matern, 1929. Right lateral view of complete carapace, GN2015003. k. Franklinella latesulcata (Paeckelmann),1921. External view of right valve, WZ15073. 1. Villozona sp. Left lateral view of complete carapace, WZ15015. Scale bars represent $200 \mu \mathrm{m}$.

\subsection{Main factors controlling the distribution of ostracods from the Hongguleleng}

\section{Formation}

Becker $(1969,1971)$ considered water salinity, temperature, depth, turbulence, oxygen content, and food supply in analyzing the ostracod distribution in the Middle

Devonian of Eifel Region, Germany and concluded that water turbulence was the 
most important factor controlling ostracods distribution. Previous works (e.g. Olempska, 1979; Beck and Bless, 1990) have shown that the Devonian ostracods increased both in diversity and frequency when water turbulence and turbidity decreased, especially specimens with large-sized smooth carapaces such as Bairdia. In most cases, increased turbidity conditions would favour the deposit-feeding ostracods, which mainly consisted of Podocopida (e.g., Bairdiocypridoidea and Bairdioidea; Lethiers and Whatley, 1994) and a few of Palaeocopida (i.e., Beyrichioidea and Paraparchitoidea; Olempska, 2008), because they could catch coarser particles easily by developed limbs (Horne et al., 2011).

Based on what discussed above, the palaeoenvironement of the Lower Member of the Hongguleleng Formation should be livable with adequate oxygen, rich food and suitable temperature for yielding abundant and varied body and trace fossils (Wang, 2016). Therefore, in this study, we agree that hydrodynamic condition could be the first factor controlling the distribution of the ostracod assemblages from the Hongguleleng Formation. Compared with the environments of offshore, the nearshore is higher water-energy and more turbid due to strongly storm. Additionally, volcanic activity was intense and frequent in the volcanic island, especially in the upper part of the Lower Member and the Middle Member of the Hongguleleng Formation. For example, a number of volcanism-influenced deposits were preserved, such as the layered euhedral feldspars in medium-to coarse-grained tempestites on the bottom of the Middle Member of the Hongguleleng Formation (Fan and Gong, 2016). Thus, the water turbidity increased significantly as storm bursting with volcanic debris and flash 
falling, causing lower abundance and diversity of ostracods in the OA2 (from nearshore) than that in the OA3 (from offshore), especially the Bairdioidea. However, the deposit-feeding of OA2 (more than $75 \%$ of total species) is more dominant, which is about $65 \%$ of total species in OA3.

Moreover, the salinity of foreshore in the Hongguleleng Formation would fluctuate because of runoff and it yields some euryhaline faunas (e.g., bivalves and serpulas) (Wang, 2016). Some Platycopina and Paraparchitoidea ostracods are interpreted as euryhaline (Bennett et al., 2012), which corresponds with their occurrence in foreshore (OA1), nearshore (OA2) even offshore (OA3) in the Hongguleleng Formation. In addition, a few large species of the advantage Hollinoidea (e.g., Hollinella Coryell, 1928 and Parabolbinella Adamczak, 1968) in the OA1 can characterize low-salinity environments such as interdistributary bays, prodelta and interdeltaic embayments (Melnyk and Maddocks, 1988; Olempska, 1999; Crasquin-Soleau et al., 2005). So salinity fluctuations may be also a factor to influence the composition apart from the hydrodynamic condition, especially to the ostracods of OA1.

\section{Palaeobiogeographical relationships indicated by ostracods}

Study of some marine fossils, such as brachiopods (Zong et al., 2012, 2016) and conodonts (Wang et al., 2016) from the Hongguleleng Formation in the western Junggar showed the isolation of the region during the early Famennian, which is also supported by the endemic ostracods (Song et al., 2017). However, many cosmopolitan species were present in diversified ostracod faunas of the Hongguleleng Formation, 
suggesting possible biogeographic relationships between the Kazakhstan Plate and South China, North America, Europe and Russian plates.

The ostracods from the Hongguleleng Formation have a particularly close connection to the faunas of South China. The species, which are common in the western Junggar, appeared earlier or simultaneously in South China (from Early to Late Devonian). For example, Fabalicypris sundarijanata Wang \& Cao, 1997 and Cryptophyllus solotensis (Krandyevsky, 1958) were reported in the Lower Devonian of Yunnan, South China (Wang and Cao, 1997; Wang et al., 1992); Bairdiocypris sichuanensis Wei, 1983 and Kummerowia suboblonga Wei, 1988 also occurred in the Lower and Middle Devonian of Longmen Mts. (Wei et al., 1983; Wei, 1988); the genus of Parasargentina Zheng, 1982 just appeared in the Silurian and Devonian of South China previously (Zheng, 1982; Wang et al., 1992). So we deduce that, one ostracod assemblages of South China might gradually have migrated northward to the Kazakhstan plate through the Devonian (Fig. 6), which shows that the South China block moved northward to the Kazakhstan plate during the Late Devonian (Scotese, 2012; Song and Gong, 2017).

In addition, the ostracod faunas from the Hongguleleng Formation reveal links between the faunas of the Russian Platform as well as the Euramerica Plate. For instance, Acratia buregiana Egorov, 1953, A. ivanovoensis Egorov, 1953 and Hollinella valentinae Egorov, 1953, occurred in the Frasnian-Famennian transition of the Russian Platform (Egorov, 1953), where Cryptophyllus solotensis (Krandyevsky, 1958) were described in the Lower Devonian (Krandyevsky, 1958; Abushik, 1990). 
Some species in the Hongguleleng Formation are same or similar to those have been reported in the western Canada (Lethiers, 1978, 1981), such as Bairdia turbinata, B. cestriensis, Moorites copelandi, Pseudobythocypris rectodorsualis, Bairdia cf. fratereleziana, Famenella cf. bisangulata. To the Europe Plate, Samarella coumiacensis Lethiers \& Casier, 1995 has been described in the late Frasnian in Coumiac of France (Lethiers and Casier, 1995); Praepilatina adamczaki Olempska, 1979 (Olempska, 1981, 1997) and Parabolbinella postaculeata Adamczak, 1968 (Adamczak, 1968) usually occurred in Holy Cross Mts. of Poland; Nehdentomis schmidti Matern, 1929 and Franklinella latesulcata (Paeckelmann),1921 were reported in the Late Devonian of Germany (Matern, 1929; Paeckelmann,1921; Rabien,1954).

On a whole, ostracods from Northern Kazakstan Plate (western Junggar) show higher similarity to South China (9 species in common), as well as Russian Platform (4 species in common), Europe (5 species in common) and North America (4 species in common) (Fig. 6). Therefore, the Late Devonian ostracods in the western Junggar are not endemic apparently due to the common fauna exchange with other plates, which implies the biological world should be in relatively weak provincialism globally during the Late Devonian (Boucot, 1988; Briggs, 1995). We deduce that the ostracods from the Late Devonian of the Kazakhstan Plate might migrate to the South China Block and Laurentia-Baltica by ocean currents and sea-level changes (Song and Gong, 2017). It also illustrates that neritic faunal exchanges may be possible along the Palaeo-Tethys mostly by oceanic circulation during the Late Devonian. For instance, 
such kind of oceanic currents along the Palaeo-Tethys ocean flowed to middle and high latitudes from low-latitude (Smith and Read, 2000; Saltzman, 2003) might have actively improved affinity between the South China, Kazakstan and the East Europe plates especially in the Frasnian, which is also supported by palaeogeography of stromatoporoids (Stock, 1990) and brachiopods (Qiao, 2012).

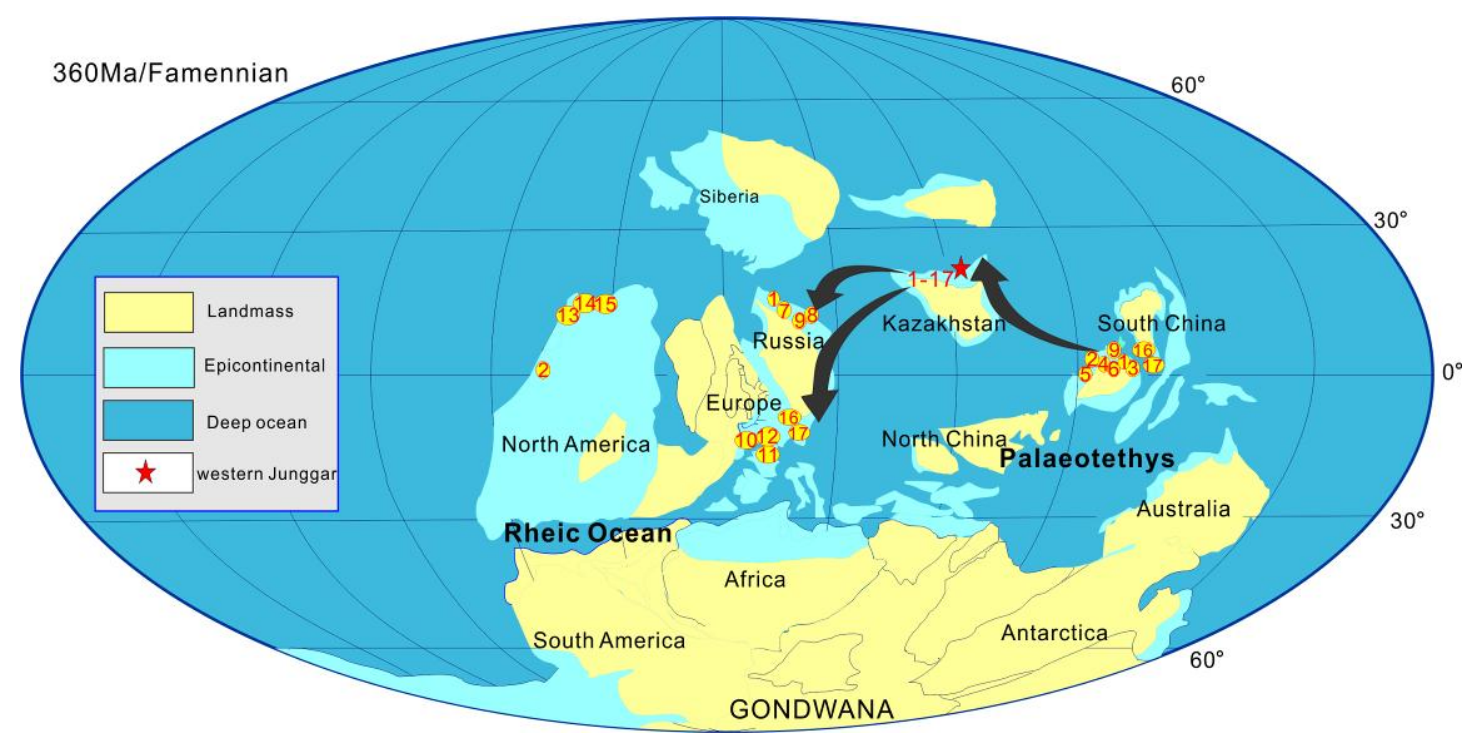

Fig. 6. Famennian palaeobiogeography of ostracods from the western Junggar (The numbers 1-17 are common species occurred in the Hongguleleng Formation and other plates. 1-Cryptophyllus solotensis (Krandyevsky, 1958); 2-Bairdia cestriensis Ulrich, 1891; 3- Fabalicypris sundarijanata Wang \& Cao, 1997; 4-Acratia cf. voronegiana Egorov, 1953 sensu Wang \&Ma, 2007; 5-Bairdiocypris sichuanensis Wei, 1983; 6-Kummerowia suboblonga Wei, 1988; 7-Hollinella valentinae Egorov, 1953; 8-Acratia buregiana Egorov, 1953; 9-Acratina ivanovoensis Egorov, 1953; 10-Parabolbinella postaculeata Adamczak, 1968;11-Samarella coumiacensis Lethiers \& Casier, 1995; 12-Praepilatina adamczaki Olempska, 1979; 13- Moorites copelandi Lethiers, 1981; 14-Bairdia turbinata Lethiers, 1981; 15-Pseudobythocypris rectodorsualis Lethiers, 1981; 16-Nehdentomis schmidti Matern, 1929; 17-Franklinella latesulcata (Paeckelmann,1921). Black arrows shows possible path of migration and communication for the ostracod faunas. Base map from Boucot et al., 2013.)

\section{Conclusions}

(1) Three assemblages of ostracods in the open oceanic island arc are first 
summarized based on ostracod faunas from the Hongguleleng Formation, i.e., OA1 (Ostracod Assemblage-1), OA2 (Ostracod Assemblage-2) and OA3 (Ostracod Assemblage-3) represent foreshore, nearshore and offshore, respectively. They are different with the ecological assemblages in continental margins.

(2) Both of the common species from the Lower Member of the Hongguleleng Formation are small-sized and thick shell with smooth or simple ornamented for living in the shallow water with high-energy and great turbulence.

(3) Hydrodynamic condition is the first environmental factor controlling composition of the ostracod assemblages from the Hongguleleng Formation. Ostracods are less abundant when water turbulence and turbidity increased, while the deposit-feeding seems more adaptable. Salinity fluctuations may also influence the composition.

(4) Many cosmopolitan species were present in diversified ostracod faunas of the Hongguleleng Formation, which suggest possible and varied biogeographic relationships between the Kazakhstan Plate and South China, North America and Russian plates. The ostracods from the Late Devonian of Kazakhstan Plate might migrate to the South China Block and Laurentia-Baltica by ocean currents and sea-level changes, which also suggests neritic faunal exchanges were possible along the Palaeo-Tethys margins during the Late Devonian.

\section{Acknowledgments}

This work was financially supported by the Natural Science Foundation of China (Grant Nos. 41290260, 
Ruiwen Zong, Dr. Zhihong Wang, Dr. Ruoying Fan, Tao Jiang, Xinsong Zhang, Kunyuan Ma, Ruochen Li,

Dongjian Li, Zhenzhong Xiang and Caohui Dong (all from Wuhan) for their joint field work.

\section{References}

Abushik, A. F., 1990. Practical Manual on Microfauna of USSR. Vol. 4. Paleozoic Ostracoda. Ministry of Geology of USSR, All-Union Geological Research Institute, Leningrad, 356 pp. in Russian.

Adamczak, F. J., 1968. Palaeocopa and Platycopa (Ostracoda) from Middle Devonian rocks in the Holy Cross Mountains, Poland. Stockholm Contributions in Geology 17, 1-109.

Bandel, K., Becker, G., 1975. Ostracoden aus paläozoischen pelagischen Kalken der Karnischen Alpen(Silurium bis Unterkarbon). Senckenbergiana Lethaea 56(1),1-83.

Becker, G., 1964. Palaeocopida (Ostracoda) aus dem Mitteldevon der Sötenicher Mulde (N-Eifel). Senckenbergiana lethaea 45(1/4), 43-113.

Becker, G., 1965. Podocopida (Ostracoda) aus dem Mitteldevon der Sötenicher Mulde (N-Eifel). Senckenbergiana lethaea 46(4/6), 367-441.

Becker, G., 1971. Paleoecology of Middle Devonian ostracods from the Eifel region, Germany. Bull. Centre Rech. Pau-SNPA 5 (suppl.), 801-816.

Becker, G., 2000. Progress in mid Palaeozoic palaeoceanographical studies from Ostracoda-from local to global importance (a review). Senckenbergiana lethaea 80(2), 555-566.

Becker, G., Bless, M. J. M., 1987. Cypridinellidae (Ostracoda) aus dem Oberdevon Hessens (Unterer Kellwasser-Kalk; Lahn-Dill-Gebiet und ostliehes Sauerland, Rechtrheinisches Schiefergebirge). Geologisches Jahrbuch Hessen 115, 29-56.

Becker, G., Bless, M. J. M., 1990. Biotope indicative features in Palaeozoic ostracods: a global phenomenon, in Whatley, R. C., Maybury, C., (Eds.). Ostracoda and global events. Chapman and Hall, London, pp. 421-436.

Becker, G., Braun, W. K., 2008. Devonian ostracods from western Canada-palaeozoogeographic implications. Senckenbergiana lethaea 88(1), 23-35.

Bennett, C. E., Siveter, D. J., Davies, S. J., Williams, M., Wilkinson, I. P., Browne, M., Miller, C. G., 2012. Ostracods from freshwater and brackish environments of the Carboniferous of the Midland Valley of Scotland: the early colonization of terrestrial water bodies. Geological Magazine 149(3), 366-396.

Boucot, A. J., 1988. Devonian biogeography: an update. In: McMillan, N. J., Embry, A. F., Glass, D. J. (Eds.), Devonian of the World, Proc. See. Int. Syrup. Dev. System Calgary 3, pp. 211-227.

Boucot, A. J., Chen, X., Scotese, C. R., 2013. Phanerozoic Paleoclimate: an atlas of lithologic indicators of climate. Society of Economic Paleontologists and Mineralogists.Tulsa, Oklahoma, USA, pp. 53-77.

Briggs, J. C., 1995. Global Biogeography. Developments in palaeontology and stratigraphy 14, Elsevier, Amsterdam, $452 \mathrm{pp}$.

Carmichael, S. K., Waters, J. A., Batchelor, C. J., Coleman, D. M., Suttner, T. J., Kido, E., Moore, L.M., Chadimová, L., 2016. Climate instability and tipping points in the Late Devonian: Detection of the Hangenberg Event in an open oceanic island arc in the Central Asian Orogenic Belt. Gondwana Research 32, $213-231$.

Carmichael, S. K., Waters, J. A., Suttner, T. J., Kido, E., DeReuil, A. A., 2014. A new model for the Kellwasser Anoxia Events (Late Devonian): Shallow water anoxia in an open oceanic setting in the Central Asian Orogenic Belt. Palaeogeography, Palaeoclimatology, Palaeoecology 399, 394-403.

Casier, J. -G., 2004. The mode of life of Devonian entomozoacean ostracods and the 
MyodocopidMega-Assemblage proxy for hypoxic events. Bulletin de l'Institut Royal des Sciences Naturelles de Belgique, Science de la Terre 74, 73-80.

Casier, J. -G., 2008. Guide de l'excursion: Les ostracodes du Dévonien Moyen et Supérieur du Synclinorium de Dinant, in: Casier, J. -G. (Ed.), Résumé des communications et guide de l'excursion $22^{\text {ème }}$ Réunion des Ostracodologistes de langue française, Bruxelles 2-4 juin. Institut royal des Sciences naturelles de Belgique, pp. 25-79.

Casier, J. -G., 2017. Ecology of Devonian ostracods: application to the Frasnian/Famennian boundary bioevent in the type region (Dinant Synclinorium, Belgium). Palaeobiodiversity and Palaeoenvironments, DOI 10.1007/s12549-017-0278-z.

Casier, J. -G., Kasimi, R., Préat, A.,1995. Les ostracodes au passage Eifelien/Givetien a Glageon (Avesnois, France) . Geobios 28 (4), 487-499.

Casier, J. -G., Olempska , E., 2008. Middle Frasnian (Devonian) ostracods from the Frasnes railway section (Dinant Synclinorium, Belgium): taxonomy, biostratigraphy, paleoecology. Bulletin de l'Institut Royal des Sciences naturelles de Belgique, Sciences de la Terre 78, 51-66.

Chen, X., Mawson, R., Suttner, T.J, Talent, J.A., Fryda, J., Mathieson, D., Molloy, P., Berkyová, S., 2009. Late Devonian (latest Frasnian-Famennian) faunas from the "Hongguleleng Formation" and the F-F boundary in northern Xinjiang, NW China. Berichte des Institutes für Erdwissenschaften, Karl-Franzens-Universität Graz (Paleozoic Seas Symposium) 14, 18-20.

Cocks, L. R. M., Torsvik, T. H., 2007, Siberia, the wandering northern terrane, and its changing geography through the Palaeozoic. Earth-Science Reviews 82(1), 29-74.

Crasquin-Soleau, S., Vaslet, D., Le Nindre, Y. M., 2005. Ostracods as markers of the Permian/Triassic boundary in the Khuff Formation of Saudi Arabia. Palaeontology 48, 853-868.

Egorov, V. G., 1953. Frasnian Ostracods of the Russian Platform. 2. - Bairdiidae, Hollinidae, Kirkhyidae. Vsesoyuznogo Neftyanogo Nauchno-issledovatelskojo Geologorazvedochnogo Instituta (VNIGRI), 1-79 in Russian.

Fan, R. Y, Gong, Y. M., 2016. Ichnological and sedimentological features of the Hongguleleng Formation (Devonian-Carboniferous transition) from the western Junggar, NW China. Palaeogeography, Palaeoclimatology, Palaeoecology 448, 207-223.

Gong, Y. M., Zong, R. W., 2015. Paleozoic stratigraphic regionalization and paleogeographic evolution in western Junggar, Northwestern China. Earth Science-Journal of China University of Geosciences 40, 461-484 in Chinese with English abstract.

Gründel, J.,1965. Zur Ausbildung und taxionomischen Bedeutung der Narben der zentralen Muskelgruppe in der Unterklasse Ostracoda. Neues Jahrbuch für Geologie und Paläontologie, Monatshefte 10, 577—597.

Horne, D. J., Cohen, A., Martens, K., 2002. Taxonomy, morphology and biology of Quarernary and living Ostracoda. In: Holmes, J. A., Chivas, A. (Eds.), The ostracoda: applications in quaternary research, Geophysical monograph, vol. 131, pp. 5-36.

Horne, D. J., Brandão, S. N., Slipper, I. J., 2011. The Platycopid Signal deciphered: responses of ostracod taxa to environmental change during the Cenomanian-Turonian Boundary Event (Late Cretaceous) in SE England. Palaeogeography, Palaeoclimatology, Palaeoecology 308(3), 304-312.

Jones, P. J., 2011. Latest Devonian (Strunian) Ostracoda from the Buttons Formation, Bonaparte Basin, Northwestern Australia: Biostratigraphy, Palaeoecology and Palaeozoogeography. Memoirs of the Association of Australasian Palaeontologists 39, 261-322.

Krandyevsky, V. S., 1958. On the first occurrence of the ostracod genus Eridoconcha in Silurian deposits of the USSR. Geologicheskiy Zhurnal Akademii Nauk Ukrainskoy SSR 18, 44-55 in Ukrainian. 
Lethiers, F., 1978. Ostracodes du Devonien terminal de la Formation Big Valley, Saskatchewan et Alberta. Palaeontographica A 162, 81-143.

Lethiers, F., 1981. Uppermost Devonian Ostracodes from the Western Canada systematic, biostratigraphy and palaeoecology. Geobios 14, 1-234.

Lethiers, F., Braun, W. K., Crasquin, S., Mansy, J. L., 1986. The Strunian event in western Canada with reference to ostracode assemblages. Annales de la Société Géologique de Belgique 109,149-157.

Lethiers, F., Casier, J. -G., 1995. The uppermost Frasnian (Upper Kellwasser) ostracodes from Coumiac (Montagne Noire, France). Revue de Micropaléontologie 38, 65-79.

Lethiers, F., Crasquin-Soleau, S., 1988. Comment extraire des microfossiles à tests calcitiques de roches calcaires dures. Revue de Micropaléontologie 31, 56-61.

Lethiers, F., Raymond, D., 1991. Les crises du Dévonien supérieur par l'étude des faunes d'ostracodes dans leur cadre paléogéographique. Palaeogeography, Palaeoclimatology, Palaeoecology 88(1-2),133-146.

Lethiers, F., Whatley, R., 1994. The use of Ostracoda to reconstruct the oxygen levels of Late Palaeozoic oceans. Marine Micropaleontology 24 (1), 57-69.

Maillet, S., Milhau, B., Vreulx, M., Danelian, T., Monnet, C., Nicollin, J. P., 2013. Ecophenotypic variation of the Devonian benthic ostracod species Cavellina rhenana Krömmelbein, 1954: A paleoenvironmental proxy for the Ardenne (France-Belgium) and Rheno-Hercynian realm. Palaeogeography, Palaeoclimatology, Palaeoecology 392, 324-334.

Matern, H., 1929. Die Ostracoden des Oberdevons. Abhandlungen der Preussischen Geologischen Landesanstalt N.F. 118, 1-100.

Melnyk, D. H., Maddocks, R. F., 1988. Ostracode biostratigraphy of the permo-Carboniferous of Central and North-Central Texas, part I: paleoenvironmental framework. Micropaleontology 34, 1-20.

Olempska, E., 1979. Middle to Upper Devonian Ostracoda from the Southern Holy Cross Mountains, Poland. Acta Palaeontologia Polonica 40, 57-162.

Olempska, E., 1981. Lower Carboniferouso stracodes of the Holy Cross Mountains, Poland. Acta Palaeontologica Polonica 26, 35-53.

Olempska, E., 1997. Changes in benthic ostracod assemblages across the Devonian-Carboniferous boundary in the Holy Cross Mountains, Poland. Acta Palaeontologica Polonica 42(2), 291-332.

Olempska, E., 1999. Silicified shallow-water ostracodes from the Early Carboniferous of South China. Acta Palaeontologica Polonica 44, 383-436.

Olempska, E., 2002. The Late Devonian Upper Kellwasser Event and entomozoacean ostracods in the Holy Cross Mountains, Poland. Acta Palaeontologica Polonica 47 (2), 247-266.

Olempska, E., 2008. Soft body-related features of the carapace and the lifestyle of Paleozoic beyrichioidean ostracodes. Journal of Paleontology 82(4), 717-736.

Olempska, E., Belka, Z., 2010. Hydrothermal vent myodocopid ostracods from the Eifelian (Middle Devonian) of southern Morocco. Geobios 43(5), 519-529.

Qiao, L., 2012. A quantitative study of global brachiopod palaeobiogeography from Frasnian (Late Devonian) to Serpukhovian (Early Carboniferous). PhD theses, Graduate University of Chinese Academy of Science, 188 pp.

Paeckelmann, W., 1921. Neue Beitrage zur Kenntnis der Geologie, Paleontologie und Petrographie der Umgegend von Konstantinopel. 1. Obersilurische und devonische Faunen der Prinzeninseln, Bithyniens und Thraziens. Abhandlungen der Preussisch Geologischen Landesanstalt, Neue Folge 60, 1 - 79.

Rabien, A., 1954. Zur Taxionomie und Chronologie der Oberdevonischen Ostracoden. Abhandlungen des Hessischen Landesamtes für Bodenforschung 9, 1-268. 
Racheboeuf, P. R., Casier, J. G., Plusquellec, Y., Toro, M., 2012. New data on the Silurian-Devonian palaeontology and biostratigraphy of Bolivia. Bulletin of Geosciences 87(2), 269-314.

Saltzman, M. R., 2003.The late Paleozoic Ice Age: Oceanic gateway or pCO2. Geology 31, 151-154.

Scotese, C. R., 2012. The Paleomap Project. www.scotese.com 2012.

Siveter, D. J., 2008. Ostracods in the Palaeozoic? Senckenbergiana lethaea 88(1), 1-9.

Smith, L. B., Read, J. F., 2000. Rapid onset of late Paleozoic glaciation on Gondwana: evidence from Upper Mississippian strata of the Mid-continent, United States. Geology 28, 279-282.

Song, J. J., Crasquin, S., Gong, Y. M., 2017. Ostracods of the Late Devonian Frasnian/ Famennian transition from Western Junggar, Xinjiang, NW China. Alcheringa 41(2), 250-276.

Song, J. J., Gong, Y. M., 2015. Ostracods from the Emuha section of Devonian-Carboniferous transition in Western Junggar. Earth Science-Journal of China University of Geoscience 40(5), 797-809 in Chinese with English abstract.

Song, J. J., Gong, Y. M., 2017. Late Devonian global ostracod palaeobiogeography. Lethaia 50, 7-25.

Stock, C. W., 1990. Biogeography of the Devonian stromatoporoids. Memoirs Geological Society, London 12, 257-265.

Suttner, T. J., Kido, E., Chen, X., Mawson, R., Waters, J. A., Fryda, J., Mathieson, D., Molloy, P. D., Pickett, J., Webster, G. D., Frydová, B., 2014. Stratigraphy and facies development of the marine Late Devonian near the Boulongour Reservoir, northwest Xinjiang, China. Journal of Asian Earth Sciences 80, 101-118.

Wang, S. Q., 1988. Late Paleozoic Ostracode Associations from South China and Their Paleoecological Significance. Acta Palaeontology Sinica 27, 91-102 in Chinese with English abstract.

Wang, S. Q., 2009. Palaeozoic Entomozoacea and Leperditicopida (ostracoda). Fossil Ostracoda of China, Vol.3. University of Science and Technology of China Press, Hefei, 251 pp. in Chinese with English summary.

Wang, S. Q., Cao, M. Z., 1997. Devonian Ostracods from Dacaozi Section of Ninglang, Yunnan -Podocopids. Acta Micropalaeontologica Sinica 14, 460-474 in Chinese with English abstract.

Wang, S. Q., Liu, Z. M., Li, Z. B., 1992. Late Silurian and Early Devonian Ostracodes from the Qujing area, Yunnan. Acta Micropalaeontologica Sinica 9, 363-389 in Chinese with English abstract.

Wang, Z. H., 2016. Late Devonian Conodont Biostratigraphy and Carbon and Oxygen Isotopic Composition in Western Junggar, NW China. PhD theses, China University of Geosciences, 137 pp.

Wang, Z. H., Becker, R. T., Aboussalam, Z. S., Hartenfels, S., Joachimski, M. M., Gong, Y. M., 2016. Conodont and carbon isotope stratigraphy near the Frasnian/Famennian (Devonian) boundary at Wulankeshun, Junggar Basin, NW China. Palaeogeography, Palaeoclimatology, Palaeoecology 448, $279-297$.

Wang, Z. H., Zong, R.W., Gong, Y.M., Wang, C. Y., 2015. Late Devonian Conodonts and Chondrichthyes from Taketai Formationin Western Junggar, NW China. Earth Science-China University of Geosciences 40, 588-596 in Chinese with English abstract.

Wei, M., 1988. Systematic palaeontology-Ostracoda, in: Hou, H. F., (Ed.), Devonian Strarigraphy, Palaeotology and Sedimentary Facies of Longmenshan, Sichuan. Geological Publishing House, Beijing, pp.277-314 in Chinese with English summary.

Wei, M., Jiang, Z. W., Xie, L. C., Li, Y.W., 1983. Palaeontological Atlas of Southwest China-Micropalaeontology Volumes-Ostracods. Geological Publishing House, Beijing, 810 pp. in Chinese with English summary.

Windley, B. F., Alexeiev, D., Xiao, W. J., Kröner, A., Badarch, G., 2007. Tectonic models for accretion of the Central Asian Orogenic Belt. Journal of the Geological Society 164, 31-47.

Xia, F. S., 1996. New Knowledge on the Age of Hongguleleng Formation in Northwestern Margin of Junggar Basin, Northern Xinjiang. Acta Micropalaeontologica Sinica 13, 277-285 in Chinese with English abstract.

Xiao, W., Huang, B., Han, C., Sun, S., Li, J., 2010. A review of the western part of the Altaids: a key to 
understanding the architecture of accretionary orogens. Gondwana Research 18, 253-273.

Xu, H. K., Cai, C. Y., Liao, W. H., Lu, L. C., 1990. The Hongguleleng Formation in Western Junggar and the boundary between Devonian and Carboniferous. Journal of Stratigraphy 14, 292-301 in Chinese with English abstract.

Zheng, S. Y., 1982. Some Silurian and Devonian Ostracodes from Jiangyou, Sichuan. Acta Palaeontologica Sinica, 21, 352-361 in Chinese with English abstract.

Zong, P., Ma, X. P., Sun, Y. L., 2012. Productide, Athyridide and Terebratulide Brachiopods Across the Devonian-Carboniferous Boundary in Western Junggar, Northwestern China. Acta Palaeontologica Sinica 51, 416-435 in Chinese with English abstract.

Zong, P., Ma, X. P., Xue, J.Z., Jin, X. C., 2016. Comparative study of Late Devonian (Famennian) brachiopod assemblages, sea level changes, and geo-events in northwestern and southern China. Palaeogeography, Palaeoclimatology, Palaeoecology 448, 298-316. 